\title{
A Model of the Commitment to Change in Higher Education
}

\author{
Erika Setyanti Kusumaputri \\ Faculty of Psychology \\ Universitas Gadjah Mada \\ $\&$ \\ Department of Psychology \\ Sunan Kalijaga Islamic University
}

\author{
Fathul Himam, Tina Afiatin, and IJK Sito Meiyanto \\ Faculty of Psychology \\ Universitas Gadjah Mada
}

\begin{abstract}
The purpose of this study was to find out the correlation between the theoretical model of the organization's capability contribution, participation, and the climate of change to the commitment to change. Subjects were Islamic University lecturers in Indonesia who experienced the organizational change. Findings reveal (a) the theoretical model designed in this study fitted the empirical data; (b) the determination coefficient $\left(\mathrm{R}^{2}\right)$ of the commitment to change was $15.1 \%$, which showed that $15.1 \%$ of the commitment to change can be explained or predicted through the organization's capability, participation, the climate of change and the open-mindedness to changes variables; (c) the model was acceptable based on the fit model test with 60.785 chi-square value and $.275(>.05)$ probability, the CFI value was .997 (almost $1)$, and the RMSEA value was .022 $(\leq .08)$. This study has found out the determining theoretical model of the commitment to change based on the organization's capability, participation, the climate of change, and the open-mindedness to changes' roles in establishing the commitment to change. The open-mindedness to changes as a mediator is significant, because without the mediator, the organization's capability, participation, and the climate of change have no effects to the commitment to change
\end{abstract}

Keywords: commitment to change, organization's capability, participation, climate of change, open-mindedness to changes

Tujuan studi ini adalah menemukan hubungan antara model teoretis kontribusi kemampuan organisasi, partisipasi, dan iklim perubahan terhadap komitmen perubahan. Subjek studi ini adalah para dosen pergurun tinggi Islam di Indonesia yang mengalami perubahan organisasi tersebut. Temuan mengungkapkan (a) model teoretis yang didesain dalam studi ini cocok dengan data empiris; (b) koefisien determinasi $\left(\mathrm{R}^{2}\right)$ dari komitmen untuk berubah adalah $15.1 \%$, yang menunjukkan bahwa $15.1 \%$ komitmen untuk berubah dapat dijelaskan atau diprediksi melalui kapabilitas organisasi, partisipasi, iklim perubahan, dan keterbukaan untuk variabelvariabel perubahan; (c) model dapat diterima berdasarkan uji model kecocokan dengan nilai chi-square 60.785 dan probabilitas .275 (> .05), nilai CFI adalah .997 (hampir 1), dan nilai RMSEA adalah $.022(\leq .08)$. Studi ini menemukan model teoretis penentu dari komitmen untuk berubah berdasarkan kemampuan organisasi, partisipasi, dan iklim perubahan, dan keterbukaan terhadap peran perubahan dalam membangun komitmen untuk berubah. Keterbukaan untuk perubahan sebagai mediator signifikan, karena tanpa mediator, kapabilitas organisasi, partisipasi, dan iklim perubahan tak memiliki dampak terhadap komitmen untuk berubah.

Kata kunci: komitmen untuk berubah, kapabilitas organisasi, partisipasi, iklim perubahan, keterbukaan terhadap perubahan

Change is an inevitable occurrence in organizations. Demands for change occurs in many different aspects of life, from individuals, social groups, institutions,

Correspondence concerning this article should be addressed to Erika Setyanti Kusumaputri, Department of Psychology Sunan Kalijaga Islamic University, Jalan Marsda Adisucipto, Daerah Istimewa Yogyakarta 55281. E-mail: erikakusumaputri@yahoo.co.id organizations, including industries. The main reasons for change originate from factors within and outside the organization. According to Cummings and Worley (1997), organizational change occurs due to problems or issues that force organizations to undergo changes. Such issues include process needs, structural changes in the industry or the market, changes in perceptions, 
changes in regulations, new knowledge that gave rise to new meanings, and innovation. The main goal of change is to enable further development of an organization.

Palmer, Dunford, and Akin (2006) stated that technological improvements, social and political pressure, segment change, and internal power that includes human resource problems, and management behaviour are among the many things that causes organizational changes. Consequently, there is constant pressure for organizations to change and this also demands the change to be undertaken seriously. According to Lewin (as cited in Schein, 1980) change is preceded by psychological disconfirmation, which is the need to reduce the maintenance of behaviour, followed by the next step which is an explanation of why the change is necessary. Interaction of forces will then occur; the force maintaining existing behaviour (reluctance to change) and the force urging the need to change.

Organizational change needs to be done successfully, swiftly, and must create a momentum. The problem is that organizations need to understand how to effectively manage change. Research stated that resistance or rejection of change processes are manifested by dysfunctional attitude (e.g., not wanting to be involved or is cynical to change) and behaviour (e.g., deviance). These can hamper the effectiveness of the organizational change implementations.

Individual factors are one of the key indicators in evaluating the success of an organizational change process. Consequently, much attention is given to factors influencing individual attitude towards change, particularly commitment to change. Studies found that individuals with high commitment to change are more receptive to change compared to those with low commitment to change. This showed that commitment to change is beneficial to an organization (Yousef, 2000; Chawla \& Kelloway., 2004; Meyer, Srinivas, Lal, \& Topolyntsky, 2007).

Support towards the process of change can be analysed by the level of commitment to change (Herscovitch \& Meyer, 2002; Meyer, Srinivas, Lal, \& Topolnytsky, 2007; Swailes, 2004; Fedor, Caldwell, $\&$ Herold, 2006). It was stated that commitment becomes an indicator of positive outcome from organizational change management (Chawla \& Kelloway, 2004)

Changes initiated by the organization will not be successful if it does not affect the domain of the individual, which means that change does not occur if it is yet to successfully change an individual within the organization (Kusumaputri, 2013). Change theories highlight the importance of commitment to change in models explaining the implementation of change processes (Armenakis, Harris, \& Field, 1999b; Klein \& Sorra, 1996). Commitment becomes the most important factor in individual support towards change (Armenakis, Harris, \& Field, 1999a; Conner \& Patterson, 1982; Klein \& Sorra, 1996). Klein and Sorra also stated that commitment is a central component of their model explaining the effectiveness of the implementation of innovation in the workplace. Piderit (2000) stated that support from members of an organization is a prerequisite of different types of success related to organizational change.

\section{Research Background}

A major problem of organizational change is that it causes tension not just for the organization as a whole, but also for the individuals within it. This means that if change is to be successfully implemented, a change strategy has to be developed, highlighting the psychological processes of individual members. Failure to acknowledge psychological processes in developing change strategy may result in failure. The importance of psychological processes in dealing with change is shown by a meta-analysis regarding member's reaction towards change. A correlation coefficient of .292 was found between change characteristics and member reaction, which means that organizational change characteristics that do not cause psychological threats will increase individual support towards change; organizational members will respond unfavourably towards change that threatens their job (Kusumaputri, 2010).

Organizational commitment that becomes a reference for the development of organizational change commitment is difficult to define and there has been no clear consensus among experts as reflected in the commitment literature. Research on commitment has always used the three component model developed by Meyer and Allen (1991). The three components were also developed into commitment to change (Meyer, Srinivas, Lal, \& Topolnytsky, 2007; Herscovitch $\&$ Meyer, 2002). In the context of organizations undergoing change, along with two commitment components (affective and normative), continuance commitment was found to have a weak and inconsistent relationship with some organizational outcomes and other organizational factors (Mathieu \& Zajac, 1990; Herscovitch \& Meyer, 2002).

Herscovitch and Meyer (2002) explained the definition of change commitment as a mindset that binds individuals to behave accordingly to achieve 
successful change implementation. This mindset reflects (a) desire to provide support to change based on the belief that there will be benefits inherent with the support; (b) understanding that there will be losses incurred when change was not supported, and (c) a sense of obligation to provide support for change

In their studies, Herscovitch and Meyer (2002) found that amongst the many profile dimensions of commitment to change, only affective and normative commitment showed high support towards change. It was explained that the natural behaviour of commitment needs to be understood in explaining the will of organization members to exceed the mini-mum prerequisites needed to achieve organizational goals. Members who feel certain towards change and wants to contribute to achieve success (affective commitment) or feels obliged to support change (normative commitment) will do more than required, and may even be willing to make personal sacrifices. On the other hand, members committed to change that prioritise loss-benefit calculations (continuance commitment) will do less than required.

A limitation of the study by Herscovitch and Meyer (2002) was that their study about the three different types of commitment was developed from a theory set in an organization that is not naturally undergoing the process of change. Another limitation is that in a change organization, among the three components, no meaningful difference was found between affective and normative commitment. Continuance commitment was not found to have a positive correlation with change-supportive behaviour, due to the change situation requiring organization members to spend more effort to achieve change, by not showing any concerns of loss and benefit calculations in supporting change. This is in relations with commitment to change and behaviour supporting change, which between the three commitment dimensions, only affective and normative commitment were found to have a positive correlation with change-supportive behaviour. On the contrary, continuance commitment does not induce changesupportive behaviour. Based on past research, further study related to the theory of commitment to organizational change needs to be undertaken in the context of an organization that is currently involved in a change process, while disregarding the effect of continuance commitment.

In a review of studies related to organizational change in the 1990s, three common characteristics related to change efforts were identified. These characteristics are organizational capabilities, refer- ring to the content of change that is occurring; climate of change, referring to how organizational members view contextual, internal problems in the organization; and participation, which reflects the participation process facilitated by the organization to successfully induce change (Armenakis \& Bedeian, 1999; Bouckenooghe, Devos, \& Van den Broeck, 2009; Van Dam, Oreg, \& Schyns, 2008).

According to Oxtoby, McGuiness, and Morgan (2002), organizational capability is defined as the ability of an organization to plan, design, and implement change strategy efficiently with all the members of the organization, to minimise negative impacts on individuals and operational processes. Changes related to organizational capability refers to the extent to which the implementation of changes in the use of organizational resources can be designed optimally to benefit the organization and its members (Walker Armenakis, \& Bernerth, 2007).

Other than organizational capability, another factor related to change is climate of change, which refers to how members of an organization attach meaning to the internal condition of an organization during the process of change (Tierney, 1998). Studies have shown that climate of change that stresses confidence towards leader and cohesiveness formed between members and leader can be considered as some ways to deal with uncertainty due to change. If the internal condition of an organization is negatively perceived, cynicism may occur, negatively affecting the success of change (Walker et al., 2007).

Organizational manager also plays a role in developing participation. Armenakis, Harris, and Mossholder (1993) explained that in planning for acceptance to change, there needed to be proactive efforts from managers to influence belief, attitude, intention, and finally behaviour as targets of change. Proactive efforts of change managers such as from leaders, superiors, or managers can be manifested through developing active participation of members (Walker et al., 2007). The importance of support and participation of all members of the organization will indicate a sense of sincerity from the manager towards the change that will last more than just a temporary program, as well as to assure members that the change is done to benefit both the individual and the organization.

In accordance to the explanation earlier, change management procedures that give an opportunity for members to participate in planning and implementing change will increase acceptance towards change (Coch \& French, 1948; Sagie \& Koslowski, 1996; 
Devoz, Buelens, \& Bouckenooghe, 2007). Communication and participation between leaders and members are included in organizational change oriented towards processes emphasised on participation facilitated by the organization (Bouckenooghe et al., 2009).

A majority of studies in the field of organizational change only tests the effects of one characteristic of organizational change towards the members of the organization (Armenakis \& Harris, 2002; Bommer, Rich \& Rubin, 2005; Oreg, 2006; Wanberg \& Banas, 2000), and there needed to be further research considering the possibility that the three characteristics may simultaneously affect commitment to change (Damanpour, 1991; Bernerth, Armenakis, Field, \& Walker, 2007; Chawla \& Kelloway, 2004; Hornung $\&$ Rousseau, 2007). The weakness in studies about organizational change need to be addressed to do further integrative research, considering the contribution of the three factors (organizational capability, climate of change, and participation) in analysing support towards change (commitment to change). It is further expected that the analysis of contribution for each factors influencing commitment can be made more thorough by adding an individual difference variable: openness to change.

Openness to change is an individual difference factor that creates a typical response towards change (Oreg, 2003; Avey, Wernshing, \& Luthans, 2008; Luthans, Norman, Avolio, \& Avey, 2008; Oreg, 2006). Not every member of a changing organization will resist change. Such resistance may possibly occur due to the reluctance of changing the existing work situation (Pulakos, Arad, Donovan, \& Plamondon, 2000).

The individual difference factor that is considered as a mediator between variables of organizational change and commitment to change is openness to change. Openness to change is defined as the will of an organizational member to be involved in internal work transition of an organization, such as changes in tasks, duties, department, or location (Van Dam, 2005; Bouckenooghe, 2010). Organizational change can create an implication, specifically that organizational members will create changes in work situations and adapt to new situation, such that openness to change is considered as an important aspect in the creation of a member's ability to adapt (Fugate, Kinicki, \& Scheck., 2004; Hall, 2002; Pulakos et al., 2000). Chawla and Kelloway (2004) conducted further studies about openness to change in predicting commitment to change. Their study showed that openness to change may indeed predict commitment to change. Commitment to change, however, was measured in their study as a turnover rate of employees; such turnover rate may not necessarily be an accurate indicator of an employee's commitment. Wanberg and Banas (2000) further explained that openness to change includes the willingness to support change. Willingness to change may not be a strong enough indicator of positive behaviour, and thus there needed to be an analysis of the result of change, namely commitment to change.

Service-based organizations such as educational institution also face demands for organizational change. Higher education organizations, as stated by Hasan and Prabowo (2005) possess a number of internal and external challenges that require them to change. A few of the challenges include graduates who are not yet capable of fulfilling the demands of society, local and global competition, national and international accreditation, conflict of interest, worry to change, as well as limited resources.

It can be stated that educational organization is unique to other organizations in terms of its members' characteristics and qualifications. Teachers and lecturers have higher qualifications and competence levels compared to individuals working in other sectors of the industry (Cummings \& Worley, 1997). Organizational change in the education field requires the support of all the available human resources in order to be successful, particularly the commitment of each member to change. Human resources in the education field include lecturers, administration personnel, and other functional staff (researchers, librarians, and archivists). Efforts to develop human resources need to affect all of these resources. Amongst the three components, however, lecturers have the most important and strategic role. Lecturers have a vital position to directly influence the quality of graduates. This is supported by the fact that lecturers have the highest authority in academic processes.

Studies in organizational change are usually conducted in Western countries in the context of noneducational organizations, namely hospitals and other business sectors. Practitioners and researchers of organizational change views educational organizations as a distinct bureaucratic system compared to other types of institutions (Klucker \& Loadman, 2000). This poses a unique challenge in its management.

Successful implementation of organizational change often requires acceptance and support of members. Studies have shown that positive attitude towards change are needed initially to ensure the success of planned changes. Commitment towards change is 
displayed by the willingness to put effort and intentions to work towards the change rather than just showing a supportive disposition. Commitment to change stresses the positive suggestion that proactive goals are not merely the reduction of resistance to change or the absence of negative attitude (Kotter \& Schlesinger, 1979; Piderit, 2000). Furthermore, Ford, Weisbein, and Plamondon (2003) showed that commitment to change differs conceptually and empirically from general organizational commitment, and it can also predict specific changerelated behaviour.

Following an analysis of the three constructs of commitment (Allen \& Meyer, 1990, 1997); Meyer \& Allen (1984, 1991); Cohen (2007); Felve, Yan, \& Six (2008); WeiBo, Kaur, \& Jun (2010)), although there were three organizational commitment that can be developed in the relationship of individuals in the organization, affective and normative commitments were shown to be optimal in motivating members to make meaningful contributions to their organization. Affective commitment reflects a commitment based on the emotional attachment between members of the organization and the organization, while normative commitment reflects a commitment based on obligations in an organization accepted by the members. Snape and Redman (2003) further showed that affective and normative commitments were significantly related to intention to participate in professional activities. Affective and normative commitments are crucial for members because it is expected to be developed and possessed by all members. It is also possible that affective and normative commitment can be made into one dimension of change. This is shown by the finding that the characteristics of affective and normative commitments are not polar opposites of each other; high affective commitment could also mean high normative commitment (Snape \& Redman, 2003; Cohen, 2007; Felve et al., 2008; WeiBo et al., 2010). In addition, commitment to change has been included to many theoretical models of change (Klein \& Sorra, 1996; Elias, 2009; Armenakis, Harris, \& Field, 1999b; Peccei, Giangreco, \& Sebastiano, 2011; Meyer et al., 2007; Herscovitch \& Meyer, 2002; Bernerth, Armenakis, Field, \& Walker, 2007; Fedor et al., 2006; Chawla \& Kelloway, 2004).

It can be concluded that commitment to change consists of two components, which are (1) supporting change implementation and (2) containing positive ideas with proactive support to change. Such components can be combined into one definition, which is commitment to change is the strong belief to change and accept changes to values and organizational goals that binds individuals to support the implementation of organizational change with active contribution of members, characterised by a love of change on obligation to support it.

Despite the growing number of studies aimed to understand organizational change, a majority of them focused on issues relevant to changes in an organizational level, rather than an individual level (Judge, Thorensen, Pucik, \& Welbourne. 1999; Vakola Tsaouis, \& Nikolau, 2003; Wanberg \& Banas, 2000). This is shown by the lack of empirical evidence in this area of study (Wanberg \& Banas, 2000) as well as a lack of attention towards the effects of change on the individual within an organization.

\section{Theoretical Analysis}

Review of analyses regarding factors influencing commitment was done by analysing various antecedents of commitment to change (Reichers, Wanous, \& Austin, 1997; Schweiger \& DeNisi, 1991; Lähteenmäki, Toivonen, \& Mattile, 2001; Walker et al., 2007; Chawla \& Kelloway, 2004; Jacqualine \& Shapiro, 1999; Cunningham, 2006; Hornung \& Rousseau, 2007). From the reviews, it was understood that some antecedents that affect commitment to change consist of the following: organizational capability, climate of organizational change, change participation process, and openness to change.

Lähteenmäki et al. (2001) explained that organizational capability is the ability of an organization to plan, design, and implement change programs in an efficient way that is relevant to different types of change. The ability of an organization to utilise resources will minimise negative impacts of change towards the individual and will increase commitment to change.

Organizations that excel in building their capability will have a competitive advantage. This means that the organization is able to get opportunities, significantly improve the operational pattern, perform innovation, restructure, use new technologies, and is capable of performing better activities. Capability to enforce change in the core competencies will improve every aspect of the organizational management.

Organizational change climate also contributes to the level of organizational change commitment. Organizational change climate refers to the organization's internal power, that is the level of professionalism, behaviour of manager towards change, 
and technical resources (Damonpour, 1991). The role of climate includes trust towards leaders, cohesiveness, and organizational politics that are important in determining the outcome of change, namely commitment to change (Bouckenooghe et al., 2009; Devos et al., 2007).

Participation process initiated by the organization is also affected by the level of organizational commitment to change. This process refers to actions by change managers during the initial change process and suggested change implementation (Devos et al., 2007). Change managers need to prepare members to change by engaging in an open and honest communication. Better facilitation of change process, highlighting communication and support from direct superiors especially in the provision of feedback, will lead to better levels of commitment to change implementations.

Individual differences need to be taken into consideration in analysing the contribution of organizational change commitment antecedents. Wanberg and Banas (2000) explained individual differences are displayed through openness to change. Organizational members' strategy to deal with change cannot be separated by individual ability to adapt to change. Individuals who see change as a challenge will face less problems adapting and thus will have high commitment to it. On the other hand, individuals who are less open to change will face difficulties dealing with change which results in low commitment.

Organizational change is characterised by the level of complexity and ambiguity related to content and consequences (Isabella, 1990). Change content which includes organizational capability, climate of change, and organizational participation are objects that enable various interpretations from members affected by the change. Individual efforts to understand change especially the characteristics of change may be affected by their social environment. In particular, peers, subordinates, and superiors in an individual's work environment may also affect how the individual himself/herself interpret the change. Pfeffer (1981) further explained that social environment can influence relative needs in understanding the effects of change. If the communicated change consists of numerous change aspects, they may exert a strong enough influence to an individual's commitment to change. Dispositional individual differences related to their understanding of aspects of change also need to be taken into account in forming change commitment. A detailed explanation of the dynamic relationship of organizational capability, climate of change, participation, and openness to change towards commitment to change is displayed in Figure 1.

\section{Aim of the Study}

Based on an analysis of previous studies regarding the construct of commitment to organizational change and previous research models, the aim of the current study is to test a theoretical model depicting the interrelationship between the variables organizational capability, climate of change, and change participation on commitment to change via openness to change. From the obtained results, the amount of contribution of each variable towards other variables can be described.

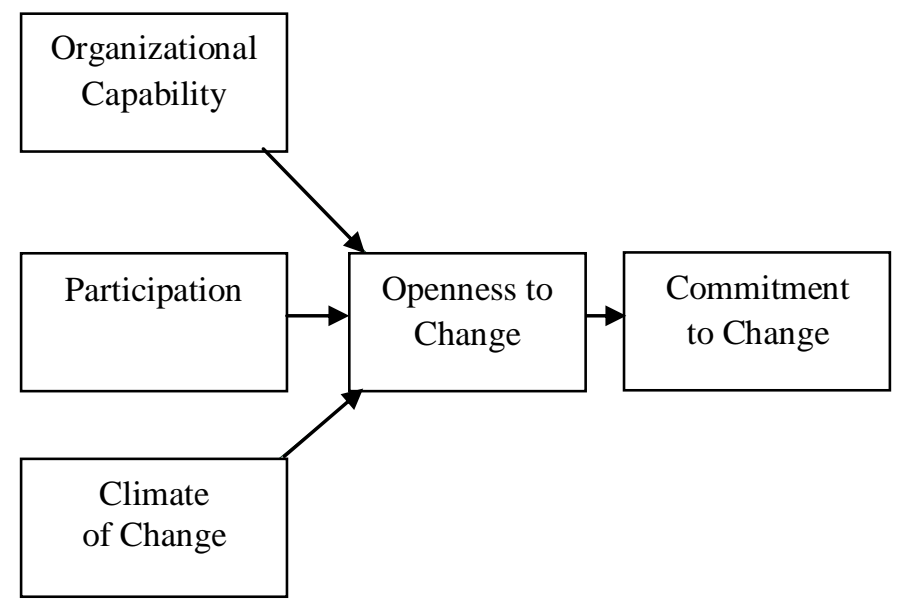

Figure 1. Contribution of organizational capability, climate of change, participation, and openness to change towards commitment to change. 


\section{Hypothesis of the Study}

In this study, it was hypothesised that organizational capability, climate of change, and participation towards change commitment will contribute to change that is mediated by openness to change.

\section{Methods}

The current study utilised a correlational design involving five research variables, which are (a) organizational capability, (b) participation, (c) climate of change, (d) openness to change, and (d) commitment to change. This study used a survey method with a scale containing a list of questions for the respondents to respond confidentially using preprepared answers.

Commitment to change ( $\mathrm{CtC})$ was developed by the author based on the concept of commitment by Herscovitch and Meyer (2002) which is commitment based on the love of change and the obligation to support change. The first aspect is a love of change which consisted of three behaviour indicators, which are proud to be involved in planning a work program, feeling happy in doing change and a match between personal values and change values. The second aspect is an obligation to support change. The indicator is obligation to successfully achieve the university's new vision and mission, obligation to know the result of evaluation of change implementation, and doing tasks according to the role in organization to support change. There are 40 items in this commitment to change scale. An example item is "I work according to the new procedure."

The organizational capability scale was designed from the concepts done by Palmer et al. (2006), Jones (2007), and Bouckenooghe et al., (2009). This scale consists of aspects related to changes of vision, mission of organization, restructuring, and use of new technology. Restructuring refers to the change of organizational structure and use of new technology is the use of technology in academic processes. This scale consists of nine items, with an example item as follows: "There is an addition of structure in the university to facilitate the achievement of organizational strategy," with a response scale ranging from 'difficult' to 'efficient.'

The scale designed to analyse climate of change was based on the concept of organizational climate of change from Boukenooghe, et al. (2009). Climate of change consists of three aspects, which are trust towards leader, cohesiveness, and politics. Trust towards leader consists of trust towards leader on implementation of policies, trusting the idea that a leader will evaluate change implementation. Cohesiveness consists of trust among members, level of competition among members. Politics consist of subjectivity in policy decision, evaluation based on a certain group, and decisions based on provisions. A total of 21 items were included in this scale, which includes "There is healthy competition among my peers."

Change process participation developed by organization was also developed from the concept by Palmer, Dunford, \& Akin (2006) and Boukenooghe et al., (2009). Change process participation consists of two aspects: communication and support from direct superior. Communication is the presence of regular meetings, clear information about change, and active involvement of members. Support from superior is the provision of support from leader to member, assistance from leaders to deal with problems, and explanation from leader about the change. This scale consists of 15 items, which includes "My superior gave systematic information when I need explanations related to the change process."

The scale of openness to change is based on the concept by Klucker and Loadman (2000). Openness to change consisted of cognition, affect, and psychomotor responses. Cognition consisted of knowledge about change and its positive impacts. Affect consisted of happiness in dealing with change implementation and pride as a member undergoing change. Lastly, psychomotor included willingness to support change and active willingness to perform change. This scale had a total of 18 items. An example item is as follows: "There is an urge to help peers that are facing difficulty facing changes."

Prior to testing construct validity, a test was done to evaluate the quality of language used, which is the starting point in quality testing which in this case refers to the items in the scales. This evaluation was qualitative and judgmental and was done by experts in the field. Language testing was done by asking the opinions of experts. From those opinions, the items were modified especially in terms of sentence structure and potential confounds of one item to another.

Next, a test was done in lecturers in private universities. Results of internal consistence and reliability testing were displayed in Table 1.

Validity testing used factorial validity, which aimed to test a variable's latent construct, taking into 
Tabel 1

Analysis of Item and Scale Reliability

\begin{tabular}{|c|c|c|c|}
\hline Variable & Factor & Item Total Correlation & Cronbach's Alpha \\
\hline \multirow{2}{*}{ Commitment to Change (CtC) } & Love of Change & $.360-.719$ & \multirow{2}{*}{936} \\
\hline & Support for Change & $.329-.527$ & \\
\hline \multirow{3}{*}{$\begin{array}{l}\text { Organisational Capability } \\
\text { (OC) }\end{array}$} & Change in Vision and Mission & $.569-.622$ & \multirow{3}{*}{.773} \\
\hline & Restructuring & $.470-.640$ & \\
\hline & Technology & $.247-.272$ & \\
\hline \multirow{2}{*}{ Participation $(\mathrm{P})$} & Communication & $.316-.479$ & \multirow{2}{*}{.758} \\
\hline & Support from Superior & $.330-.389$ & \\
\hline \multirow{3}{*}{ Climate of Change (CoC) } & Trust towards Leaders & $.413-.723$ & \multirow{3}{*}{.891} \\
\hline & Cohesiveness & $.296-.435$ & \\
\hline & Politics & $.356-.501$ & \\
\hline \multirow{3}{*}{ Openness to Change (OtC) } & Cognitive & $.376-.583$ & \multirow{3}{*}{.815} \\
\hline & Affective & $.283-.509$ & \\
\hline & Psychomotor & $.254-.405$ & \\
\hline
\end{tabular}

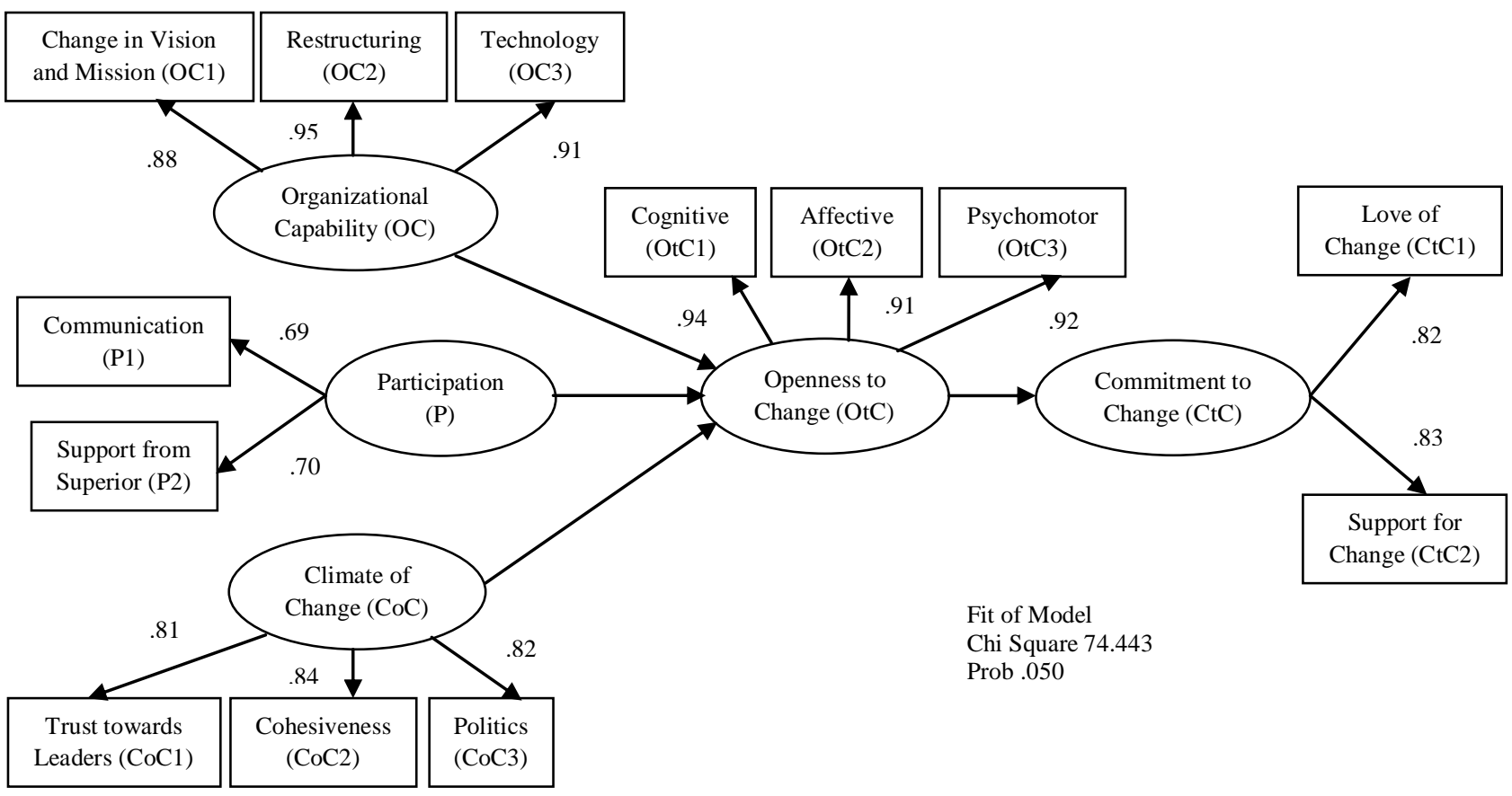

Figure 2. Measurement model test.

account correlation among variables and testing observed variable within a latent variable which needed exploratory analysis and confirmatory factor analysis (Netemeyer, Bearden, \& Sharma, 2003). In this study factorial validity test used confirmatory analysis to confirm the items used, if the item measured only one factor and not part of other, unidimensional factors. In the statistical analysis it was shown that a large factor loading on an item should be found on one factor, not on others. Said confirmatory factor analysis was aimed to test whether the items belong to the same measurement unit measuring the same construct. In the statistical analysis this is shown with a factor loading greater than .5 (Netemeyer, Bearden, \& Sharma, 2003).

In the commitment to change (CtC) variable, factor analysis results showed factor loading changed from $.492-.854$ and Cronbach's alpha coefficient 
Table 2

Factor Loading of Research Measures

\begin{tabular}{lcr}
\hline Latent Variable & $\begin{array}{c}\text { Observed } \\
\text { Variables }\end{array}$ & Factor Loading \\
\hline Commitment to & CtC1 & .82 \\
Change (CtC) & CtC2 & .83 \\
& & \\
Openness to Change & OtC1 & .94 \\
(OtC) & OtC2 & .91 \\
& OtC3 & .92 \\
Organizational & OC1 & .88 \\
Capability (OC) & OC2 & .95 \\
& OC3 & .91 \\
& & .69 \\
Participation (P) & P1 & .70 \\
& P2 & .81 \\
Climate of Change & CoC1 & .84 \\
(CoC) & CoC2 & .82 \\
\hline
\end{tabular}

Tabel 3

Goodness of Fit Criteria

\begin{tabular}{lr}
\hline Measurement Index Criteria & Reference Value \\
\hline Chi-square $\left(X^{2}\right)$ & As small as possible \\
Degrees of freedom & $\geq 0.05$ \\
$\rho$-value & $\leq 2.00$ \\
CMIN/df $\left(\right.$ relative $\left.^{2}\right)$ & $\leq 0.08$ \\
RMSEA & Approaching 1 \\
GFI & Approaching 1 \\
AGFI & Approaching 1 \\
TLI & Approaching 1 \\
CFI & \\
\hline
\end{tabular}

of .936. An item had a score of .492 (lower than .5). This item is not discarded but the sentence structure and meaning were fixed. Organizational capability (OC) moved from .682 to .904) with a Cronbach's alpha coefficient of .773. Climate of organizational change moved its factor loading from .637 to .873 with a reliability coefficient of .891 . Factor loading of openness to change was .542 to .875 with a reliability coefficient of .815 .

In addition, confirmatory factor analysis was also done to obtain convergent validity shows the degree to which two measurements designed to measure the same construct are related with one another. Convergence is obtained if two measures of the same construct were found to be highly correlated. Ferdinand (2002) and Wijaya (2009) stated that convergent validity was evaluated from a measurement model that shows whether every estimated indicator can be estimated to measure every tested dimension of a tested concept in a valid manner. If each indicator has a critical ratio greater than twice its standard error, then it can be concluded that the indicator is valid.

In this study, a test of measurement model was done with confirmatory factor analysis simultaneously within structural equation modelling. Criteria of acceptance for factor model was done with a criteria to show whether the produced model is equal to the hypothesised model, which as little chi-square value $\left(X^{2}\right)$ as possible; $\rho$-value $\geq .05$

Figure 2 explained that the observed variable was sufficient in explaining the latent variable from the size of the measurement's factor loading. In the scale of commitment to change (SCtC), factor loading moved equally, which is .82 - .83. From the result, it can be seen that the factor loading of SCtC revealed that items related to pride of members when involved in planning work programs, happiness in doing change, and a match between personal values with organizational change can explain commitment to organizational change variable.

Table 2 displayed the result for the observed variable in explaining latent variables from the factor loading of the measurements.

Participants in this study consist of lecturers in two Indonesian Islamic Universities who were undergoing change management status from an institute to a university. In the data collection process, a total of 214 scales were successfully returned and analysed.

Samples were obtained with a non-probability sampling, which means that not every member had the same chance to become respondent, according to subject characteristics. The technique used was quota sampling, which means that the author chooses the samples from a quota that was made prior to the data collection, which meant to reflect the population (Kerlinger, 2000).

Obtained quantitative data were analysed using structural equation modelling (SEM). This is done to calculate the strength of the hypothesis between variables in a theoretical model with a mediating variable (Maruyama, 1998) and is supported by the AMOS version 20 statistics program. In this research, antecedents of commitment to change, which included organizational capability, participation, and climate of change, via openness to change will be observed in terms of their strength in influencing commitment to change.

Structural equation modelling provided an estimate of strength of the inter-variable hypothesis in a theo- 
Table 4

Coefficient of Determination of Each Research Variables

\begin{tabular}{lccr}
\hline Exogenous Variable & Endogenous Variable & $\begin{array}{c}\text { Coefficient of } \\
\text { Determination (R2) }\end{array}$ & $\begin{array}{c}\text { Effective } \\
\text { Contribution (\%) }\end{array}$ \\
\hline $\begin{array}{l}\text { Organizational Capability (OC) } \\
\text { Participation (P) }\end{array}$ & Openness to Change & .098 & .211 \\
Climate of Change (CoC) & (OtC) & & .176 \\
& & & .180 \\
Organizational Capability (OC) & & .151 & .391 \\
Participation (P) & Commitment to Change & & -.036 \\
Climate of Change (CoC) & $(\mathrm{CtC})$ & -.059 \\
Openness to Change (OtC) & & .038 \\
\hline
\end{tabular}

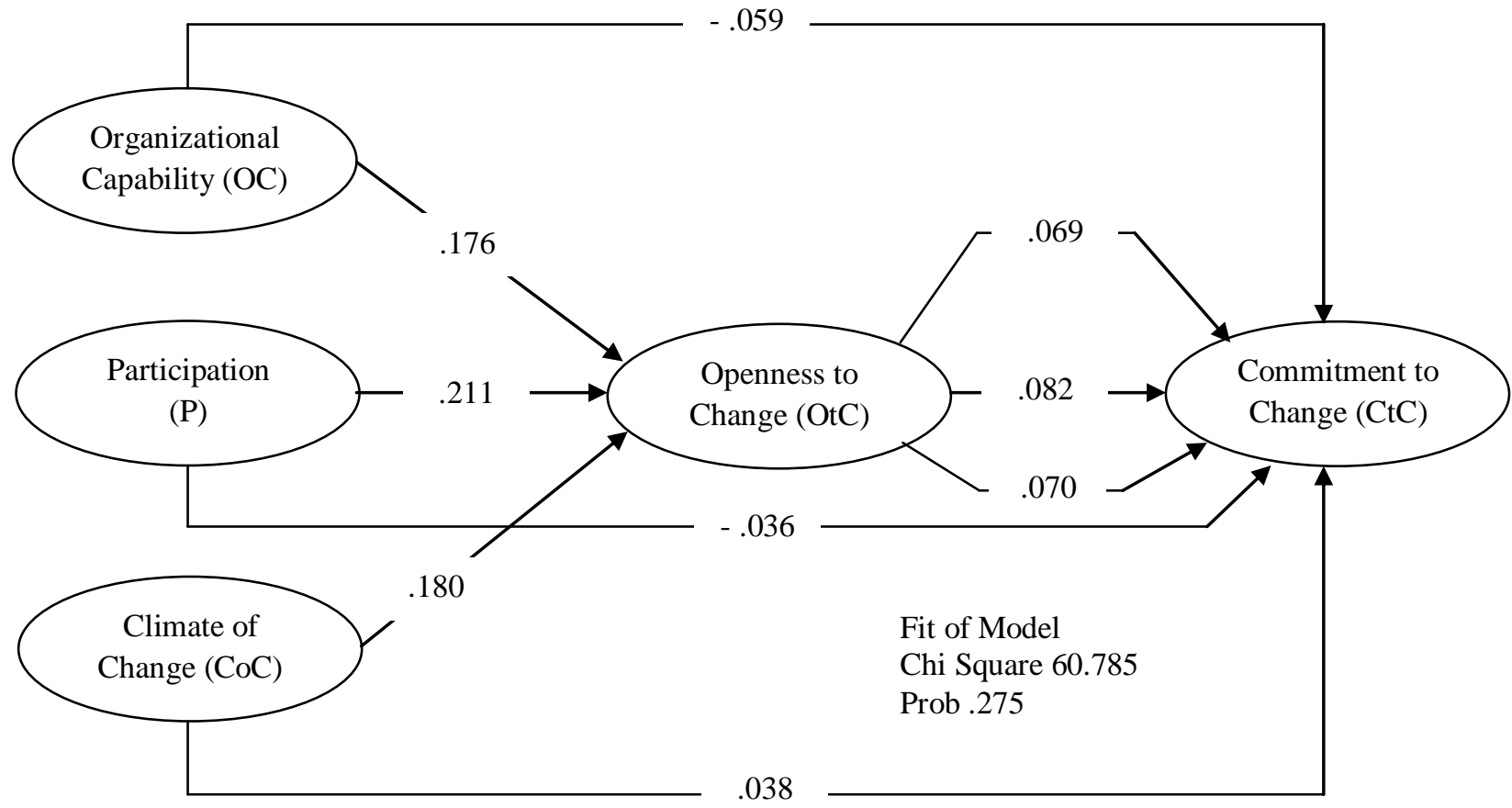

Figure 3. Test of commitment to change model.

retical model. This equation gave information about the hypothesis directly from one variable to another, as well as the mediating variable. A fit between the theoretical model with the empirical data was expressed in a goodness of fit value. An indicator of goodness of fit test is presented in Table 3 .

\section{Results}

From the model fit test of the theoretical model of the cause of commitment, the following results were found. The chi-square value was 60.875 with $p$ $=.275(>.05)$; RMSEA value was $.022(\leq .08)$, and the CFI value was .997 (approaching 1). These results indicated that the fit test has met the requirements. The theoretical model positing an influence of capability, organizational climate, and participation on commitment to change that was mediated by openness to change was thus accepted. Figure 3 illustrates the model:

Coefficients of determination of each exogenous and endogenous variable were provided in Table 4. Variables organizational capability, participation, and climate of change simultaneously gave a direct effect on openness to change of .098 or $9.8 \%$. Coefficient of determination along with exogenous variables organizational capability, participation, and 
change climate were strengthened by openness to change to commitment to change by .151 or $15.1 \%$.

Indirect effect is the extent to which the role of exogenous variables on the endogenous variable is strengthened by the mediating variable (presented in Table 5). The mediating variable, which is openness to change, is significant if it strengthens the relationship between organizational capability, participation, and organizational climate towards commitment to change.

Table 5 reveals that openness to change was a significant mediator between participation towards openness to change $(\beta=.082)$, organizational capability towards commitment to change $(\beta=.069)$, and change climate towards commitment to change $(\beta=.070)$.

From the indirect effects, participation was found to have the biggest indirect effect on commitment to change compared to organizational capability and climate of change. Change process can be seen from the occurring change participation process, which is the ongoing communication pattern and direct support from superior. How change is communicated is important to determine success. The importance of communication during change is related with facilitating vision, increasing feedback, providing social support, and assisting with modification of change especially in designing change strategies. Nevertheless, all determinants of change commitment were found to have significant contribution, and this is strengthened by openness to change. This indicated that the ability of members to adapt to change is needed to develop commitment to change. Thus, the current research hypothesis, stating that there will be positive contributions of organizational capability, change climate, and participation towards commitment to change mediated by openness to change, is accepted.

\section{Discussion}

The aim of this study was to test a theoretical model depicting the interrelationship between variables namely organizational capability, climate, and organizational change participation on commitment to change through openness to change. It was hypothesised that organizational capability, change climate, and participation will contribute to commitment to change, mediated by openness to change.

The model of commitment to change aimed to explain how individuals undergo changes in organi-
Tabel 5

Indirect Regression Coefficient of Exogenous Variables on Commitment to Change Mediated by Openness to Change

\begin{tabular}{llr}
\hline $\begin{array}{l}\text { Exogenous } \\
\text { Variable }\end{array}$ & $\begin{array}{l}\text { Endogenous } \\
\text { Variable }\end{array}$ & $\begin{array}{r}\text { Indirect } \\
\text { Effect }\end{array}$ \\
\hline Participation (P) & $\begin{array}{l}\text { Commitment to } \\
\text { Change (CtC) }\end{array}$ & .082 \\
$\begin{array}{l}\text { Organizational } \\
\text { Capability (OC) }\end{array}$ & .069 \\
$\begin{array}{l}\text { Climate of Change } \\
(\mathrm{CoC})\end{array}$ & .070 \\
\hline
\end{tabular}

zations, and thus giving a thorough understanding about the process of change, its impact on individuals, and strategies used to help members to achieve the desired goal.

Organizational change that occurs indicated the need to change in an individual's self. Indeed, individual change is closely related to the learning process from an old situation into the new one. Buchanan and Huczynski (1985, as cited in Cameron \& Green, 2004) defined learning as a process to acquire knowledge from experience that results in a change of behaviour. Learning is not simply getting knowledge, but also applying it through new ways of doing things.

Numerous change scenarios require the self to learn something new or to adapt with new operational activities. In old situations, individuals work with automatic processes done through habit. In a new situation, individuals need a mindset that not only requires time, but also psychological space to reduce tension.

Wanberg and Banas (2000) and Bouckenooghe, et al. (2009) explained that in this situation, understanding the reaction of organizational members on change is an important component in managing the whole process of change. Those who do not participate in designing and implementing change will not experience the impact of change. This will indicate that whoever is directly involved in decisions related to change will react differently; they will support change by being committed to it compared to those who are not involved.

In industrial and organizational psychology, commitment to change has an ability to predict behaviour to support change (Herscovitch \& Meyer, 2002). The interrelated process between behaviour and attitude has been formalised in numerous theoretical models. MODE (Motivation and Opportunity as Determinants of Behaviour) assumed that attitude drives behaviour through automatic processes and 
evaluation period. On the other hand, cynicism towards organizational change indicated negative behaviour manifested as being critical to the organization, lowered job satisfaction, and decreasing commitment (Ferres \& Connell, as cited in Boukenooghe, 2010; Wanous, Reichers, \& Austin, 2004).

Members of organization also need the ability to adapt, which is openness to change. Therefore, there needed to be a clearer analysis of how individuals go through change. Commitment to change is the essence of successful organizational achievement.

Success or failure of organizational change indicate a conclusion that other factors other than macrolevel variables, which are micro-variables directly related to individuals within an organization, also have an important role in successfully enforcing organizational change. As an alternate perspective, a number of researchers have adopted micro-level perspective on change through testing individuals in an organization and psychological factors influencing changes (Elias, 2009; Walker et al., 2007; Wanberg \& Banas, 2000; Lines, 2005; Boukneooghe, 2010; Van Dam, 2005).

Change processes in universities possess certain unique qualities that are not found in other organizations. This is because of the different competencies acting as the main difference in human resources. Lecturers as research subjects have the highest level of competence compared to administration staff and librarians. A collegial method is appropriately used in higher education organization in designing change strategies which result in their successful application. Participation, in particular, was found in this study to have a better predictive value to commitment to change through openness to change $(\beta=.082)$. The process of participation highlighted processes facilitated by organizations or institutions in acquiring suggestion or feedback from members. Lecturers, as ones having better competence in terms of human resources compared to others, will feel more appreciated if participation is continuously fostered by the organization.

Results of the current study support that of previous research which noted that the standard of successful change was individual acceptance (Conner \& Patterson, 1982; Scheneider, Brief, \& Guzzo, 1996; Chawla \& Kelloway, 2004; Fedor et al, 2006; Luthans et al, 2008; Elias, 2009), which in this study is represented by commitment to change. A difference of the current study compared to previous studies is that past studies only highlighted suc- cessful change through technological advances, developed organizational structure, and sufficient systems (Palmer et al., 2006) where the standard of successful change were mostly attributed to tangible aspects such as adopting new technology and development of infrastructure.

Results of this study also provided a new development on the commitment to change construct that is distinct from the study by Herscovitch and Meyer (2002) who stated that commitment to change is different to organizational commitment that initially comprised of three dimensions which are affective, normative, and continuance commitments. Commitment to change found by Herscovitch and Meyer originated from organizational commitment, and evidence showed that continuance commitment had a contradictory nature with affective and normative commitment, which made it unable to predict changesupportive behaviour. The commitment construct of the present study is uni-dimensional and continuous in nature, originated from the combination of affective and normative commitment, and contextually tested in an organization that is naturally undergoing change.

Values related to change were based on humanistic psychology. Such values emphasise on the importance of developing individual competence in work organization as well as assisting them to achieve satisfaction. Palmer et al. (2006) explained that humanistic values highlight openness, honesty, and integrity. Therefore, the aforementioned change was focused on the individual and not on management or material benefits of the organization.

Member support towards change is a result of the evaluation of the change implementation process. In the initial part of the change process, when information about change decision was first communicated, organizational members form beliefs about change. Such beliefs emphasize the extent to which the change will impact an individual's work characteristics, how far an organization can implement change focusing on objectivity, and the extent to which the change fits with personal values (Armenakis et al., 1993).

Strategies to increase change commitment need to prioritise participation process that help members realise that the leader will always support them, help them address potential issues, communicate information related to progress and evaluate change. Participation is prioritised to increase acceptance towards change. As such, organizational managers need to take into account suggestions from members. Organizations that are successful are capable of en- 
couraging individuals to share information, affect, comfort, and to supportive towards each other. Individuals with adequate social support will usually experience improved mental and physical conditions under highly stressful conditions.

Openness to change that takes into account member participation is the main determinant of creating commitment to change. This finding is in line with the research by Rousseau and Tijoriwala (1999) asserting from a social perspective that trustbased organizational management can drive members to accept organizational change. In a collectivistic culture, commitments that are dominantly formed in a member are affective and normative commitments (Felfe et al., 2008). It was stated that organizational members with a collectivistic orientation often develop a close relationship with other members and respect social identity. Therefore, participation and change climate emphasising on communication, superior support, cohesiveness, trust towards leader, and politics all influence openness to change. Those factors shape commitment to change. This is shown by the indirect effect of the exogenous variable towards commitment to change. Results of the present study found that, compared to other variables, participation showed the largest effect $(\beta=.082)$ followed by climate of change $(\beta=.070)$ and organizational capability $(\beta=.069)$.

On participation developed by organization, management of change requires a communication strategy and skilful management focused on change implementation. There needed to be a design or participation process strategy created by organization through communication that does not feel too controlling, but is capable of decreasing feelings of incapability, burden, or even frustration. The importance of change communication process and monitoring or evaluating change implementation are related with the role of manager (leader); it is crucial to be done through communicating successes, challenges, and obstacles in carrying out the change management system.

Aside from addressing the emotional aspect, new employees need to be given self-development opportunities to learn new things that are required by the organization. The organization could facilitate seminars, workshops, or other training models that could nurture moral obligation from members to support change.

The occurring change need to be manifested in the creation of new vision and mission, restructuring, and the adoption of technology, all of which indicate the capability of an organization. The present research showed that organizational capability is closely related to commitment to change mediated by openness to change $(\beta=.069 ; p=.05)$.

Climate of change is important when trust of members to leader, camaraderie based on trust among members, and competition between members does not dominate. These things can be nurtured in an organizational environment, and politics as a natural condition in implementing change strategy need to be controlled for the benefit of the organization and the group. Methods to manage political dynamics in organizational change are often ignored in organizational change studies. This is because organizational change that arrived in the intervention stage to improve organizational condition has already been done on the level of organizational development. Organizational development that is commonly done is rooted on the humanistic tradition that emphasises collaboration and equal distribution of power between individuals and groups.

In a natural context, modern day organizations are inseparable from political elements representing different factions that affect the dynamics of the organization. This poses as a challenge for organizational change that is influenced by a humanistic perspective, especially in organizations with a dominant political element. Explanations regarding group norms as a reference of group approaches, political perspective does not absolve an organization from being tied to the needs of certain groups. Each group or coalitions will compete for influence as well as available resources. A natural condition will occur when a certain group possesses more influence compared to other groups. Groups that become powerless due to change will react defensively and tend to try to maintain the status quo.

The organizational entity includes an individual's work, workgroup, organizational strategy, programs, products, or the whole activity of organizations. Arriving at an individual level, not every worker in the organizational environment has an openness to change, shown by the ability to adapt to the change that is occurring. Some of them are scared to find difficulties when required to adopt a new procedure or workflow in doing their tasks.

Organizational members who are open to change tend to display flexibility when faced with new challenges. Openness to change is a strong predictor of an individual's willingness to participate in work transitions. Organizational members who typically have a more adequate openness to change will be 
more open to dealing with organizational change compared to those who lack the quality. This is shown in the current research when exogenous variables which include organizational capability, climate of change, and participation are related with commitment to change mediated by openness to change. The result of this research showed that the correlation between exogenous, mediator, and endogenous variables increase significantly compared to when the exogenous and endogenous variables did not include a mediator.

According to Lewin (Cummings \& Worley, 1997; Cameron \& Green 2004), organizational change occurs in three stages: (a) unfreezing, planning motivation to change, (b) learning new concepts and meanings from old concepts, and (c) internalising new concepts and meanings. Along the initial stage of unfreezing, organizational members do not learn new things before they obtain all the focus to learn new things.

The resulting model of change commitment described individual dynamics through change, that change implementation focuses on understanding the process of change and its effects on individuals, the planned strategy highlights the determinants of commitment to change which were organizational capability, participation, climate of change and openness to change. The designed strategy is utilised to help individuals undergo changes to ensure them to achieve the desired results.

This theoretical model brings an understanding that individuals in a group need to develop a psychological realisation regarding the need to change to adapt. In developing support to change in the form of commitment, organizations need to design change implementation that emphasises the three determinants of commitment (organizational capability, climate of change, and participation) by considering member's openness to change. Psychological support and participation are strategies that are needed to achieve success.

There needed to be a holistic approach based on soft management to increase organizational capability, climate of change, and participation on change occurring in higher education. This holistic approach highlights the need to increase lecturer quality, improve study environment that stimulates study situation and open attitude, and develop informal learning in situation where there is a change process that is difficult to ask formally and requires immediate feedback from a superior. This holistic approach based on soft management also focuses on the collegial process between members and their leader. It is hoped that lecturers would be able to embrace change and feel that they are involved in it.

Lecturers need to know that policies and work procedures are in accord with the change process. There needed to be an understanding that the organization is able to optimally utilise available resources with efficient design of organizational structure and facilitate members to coordinate. The created vision and mission are also needed by members to reach the change goals. The used technology need to be utilised optimally to support new work behaviour that occurred due to change. Technology as combination of machines, techniques, and work procedures functions to process input to output. These are used to support the effectiveness of organizational activities especially in higher education.

The pattern of participation created by organizations need to be interpreted proactively. The characteristic of an education organization is predominated with the collegial relationship of its members, due to the unique variation of their qualifications, which are lecturers, research staff, library staff, and administration. Lecturers who possess higher quailfications compared to other staff need to be optimally involved in regular communication with managers. In addition, potential problems need to be explained to leaders to get clear feedback and understanding.

Climate of change which is a reflection of member perception towards process indicates trust towards leader, cohesiveness, and politics. Trust needs to be built between members and leader who initiate change and brings organizations to undergo change. Lecturers need to consider that the provision of feedback and policies in organization are done to reinforce new work behaviour, and as such university managers need to plan them systemically and continually. Additionally, the lecturer work force in the level of faculty or study program needs to be optimised in its function as a buffer to deal with forming new work behaviour that could potentially make them worried. Trust between members with groups of lecturers need to be nurtured so that the learning process during change becomes easier to manage.

The most important thing, however, is the lecturer's capability to manifest openness to change, in the ability to adapt to situations that could potentially create uncertainty and insecurity on staff members. Openness to change can also be displayed in members' willingness, especially lecturers to teach or share information to others who need support in 
dealing with problems due to change. This openness to change is the key thing that connects efforts done by the organization to actualise change-supportive reaction in the form of commitment to change.

Organization as a living entity, which is an adaptive system, an open system, as a set of interacting sub-systems designed to balance the pressure of the environment with the internal needs of individuals and groups within it. The needs of individuals and groups within the organization as wells as needs from the environment need to be met; this is called an adequate and adaptive function in the whole system. Focus of change is oriented to positive change, which means that the thought of change is something that could create opportunities to repair organizational situation or increase its competitive power and motivate individuals to work better.

\section{Limitations}

Future studies need to explore change theories that are sufficiently adequate in synergising the various levels and describing changes between levels, including the level of groups and organization. The individual and collective levels need to be analysed in a meso- or macro- level, thus creating a theory that is more thorough.

In addition, it is important to include other research subjects other than lecturers in the university, such as administration staff, functional research team, and librarians.

\section{Conclusion}

The present commitment to change model showed a fit between the theoretical concepts, namely that organizational capability, climate of change, and participation all influence commitment to change by involving openness to change as a mediator. Openness to change becomes a mediator that determines the making of commitment to change. This is shown by the significant increase of inter-variable (exogenous, mediator, and endogenous) correlation compared to when the correlation between exogenous and endogenous variables did not involve openness to change as a mediator.

\section{References}

Allen, N. J., \& Meyer, J. P. (1990). The measurement and antecedents of affective, continuance, and normative commitment to organization. Journal of Occupational Psychology, 63, 1-18

Allen, N. J., \& Meyer, J. P. (1997). Commitment in the workplace: Theory, research, and application. California: Sage Publications

Armenakis, A. A., \& Harris, S. G. (2002). Crafting a change message to create transformational readiness. Journal of Organizational Change Management, 15, 169-183.

Armenakis, A. A., Harris, S. G., \& Mossholder, K. (1993). Creating readiness for organizational change. Human Relations, 46, 681-703.

Armenakis, A. A., Harris, S., \& Field, H. (1999a). Paradigms in organizational change: Change agent and change target perspective. Handbook of Organizational Behavior, New York: Marcel Dekker

Armenakis, A., Harris, S., \& Field, H. (1999b). Making change permanent: A model for institusionalizing change intervensions. Research in Organizational Change and Development, 12, 97-128

Armenakis, A., \& Bedeian, A. G. (1999). Organizational change: A review of theory and research in the 1990s. Journal of Management, 25, 293-315.

Avey, B. J., Wernsing, T. S., \& Luthans, F. (2008). Can positive employees help positive organizational change? Impact of psychological capital and emotions on relevant atitudes and behaviors. Journal of Applied Behavioral Science, 44, 48-70.

Bernerth, B. J., Armenakis, A. A., Field, H. S., \& Walker, H. J. (2007). Justice, cynism, and commitment: A study of important organizational change variables. The Journal of Applied Behavioral Science, 43, 303-326.

Bommer, W. H., Rich, G. A., \& Rubin, R. S. (2005). Changing attitudes about change: Longitudinal effects of transformational leader behavior on employee cynicism about organizational change. Journal of Organizational Behavior, 26,733-753.

Bouckenooghe, D. (2010). Positioning change recipients' attitudes toward change in the organizational change literature. The Journal of Applied Behavioral Science, 46, 500-531.

Bouckenooghe, D., Devos, G., \& Van den Broeck. H. (2009). Organizational change questionnaireclimate of change, process, and readiness: Development of a new instrument. The Journal of Psycho$\log y, 143,559-599$.

Cameron, E., \& Green. M. (2004). Making sense of change management. A complete guide to the models, tools \& techniques of organizational change. British library in Publication Data. UK. London. 
Chawla, A., \& Kelloway. (2004). Predicting openness and commitment to change. Leadership \& Organizational Development Journal, 25,485-498.

Coch, L., \& French, J. R. P. (1948). Overcoming resistance to change. Human Relations, 1, 512-532.

Cohen, A. (2007). Commitment before and after: An evaluation and reconceptualization of organizational commitment. Human Resource Management Review, 17, 336-354

Conner, D. R.,\& Patterson, R. W. (1982). Building commitment to organizational change. Training and Developmental Journal, 36,18-30.

Cummings, T. G., \& Worley, C. G. (1997). Organization development and change (6th ed.). Cincinnati, Ohio: South Western College Publishing. An International Thomson Publishing Company.

Cunningham, G. B. (2006). The relationships among commitment to change, coping with change, and turnover intentions. European Journal of Work and Organizational Psychology, 15, 29-45.

Damanpour, F. (1991). Organizational innovation: A meta-analysis of effects of determinants and moderators. Academy of Management Journal, 34, 555-590.

Devos, G., Buelens, M., \& Bouckenooghe, D. (2007). Content, context, and process to understanding openness to organizational change: Two experimental study. The Journal of Social Psychology, 147, 607-629.

Elias, M. S. (2009). Employee commitment in times of change: Assessing the importance of attitudes toward organizational change. Journal of Management, 35, 37-55.

Fedor, D. B., Caldwell, S., \& Herold, D. M. (2006). The effects of organizational changes on employee commitment: A multilevel investigation. Personnel Psychology, 59,1-29.

Felve, J., Yan, W., \& Six, B. (2008). The impact of individual collectivism on commitment and its influence on organizational citizenship behavior and turnover in three countries. International Journal of Cross Cultural Management, 8, 211-237.

Ferdinand, A. (2002). Structural equation modeling dalam penelitian manajemen (Ed. 2). Semarang: BP Undip Seri Pustaka Kunci.

Ford, J. K. Weisbein, D. A., \& Plamondon. K. E. (2003). Distinguishing organizational from strategy commitment: Linking officers's commitment to community policing to job behaviors and satisfactions. Justice Quarterly, 20, 159-185.

Fugate, M., Kinicki, A. J., \& Scheck, C. L. (2004). Employability: A psycho-social construct, its dimen- sions, and applications. Journal of Vocational Behavior, 65,14-38.

Hall, D. T. (2002). Careers In and Out of Organizations. Thousand Oaks, CA: Sage Publications.

Hasan, L., \& Prabowo, H. (2005). Program implementasi penjaminan mutu UIN Sunan KalijagaJogjakarta (Unpublished manuscript). UIN Sunan Kalijaga.

Herscovitch, L., \& Meyer, J. P. (2002). Commitment to organizational change: Extension of a threecomponent model. Journal of Applied Psychology, 87, 474-482.

Hornung, S., \& Rousseau, D. M. (2007). Active on the job-proactive in change: How autonomy at work contributes to employee support for organizational change. The Journal Of Applied Behavioral Science, 43, 401-426.

Isabella, L. (1990). Evolving interpretation as change unfold: How managers construe key events. Academy of Management Journal, 33, 7-41.

Jacqueline, A. M., \& Shapiro, C. (1999). Employee participation and assessment of an organizational change intervention: A three-wave study of total quality management. The Journal Of Applied Behavioral Science, 35, 439-456.

Jones, G. R. (2007). Organizational theory, design, and change $\left(5^{\text {th }}\right.$ ed.). Texas: Pearson Education.

Judge, T. A., Thoresen, C. J., Pucik, V., \& Welbourne, T. M. (1999). Managerial coping with organizational change: A dispositional perspective. Journal of Applied Psychology, 84, 107-122.

Kerlinger, B. F., \& Lee, B. H. (2000). Foundation of behavioral research. Orlando USA: Harcourt Inc.

Klein, K. J., \& Sorra, J. S. (1996). The challenge of innovation implementation. Academy of Management Review, 21, 1055-1080.

Klucker, B. M., \& Loadman, W. E. (2000). Measuring principals' openness to change on three dimension: Affective, cognitive, and behavioral. Journal of Instructional Psychology, 26, 451-468

Kotter, J., \& Schlesinger, L. (1979). Choosing strategies for change. Harvard Business Review, 57, 106-114.

Kusumaputri, E. S. (2010). Studi meta-analisis reaksi terhadap perubahan organisasi. Jurnal Psikologi, 3, 87-106.

Kusumaputri, E. S (2013). Kontribusi kapabilitas organisasi, partisipasi, iklim perubahan terhadap komitmen pada perubahan melalui keterbukaan pada perubahan di institusi perguruan tinggi (Unpublished dissertation). Universitas Gadjah Mada,Yogyakarta 
Lähteenmäki, S., Toivonen, J., \& Mattila, M. (2001). Critical aspects of organizational learning research and proposals for its measurement. British Journal of Management, 12, 113-129.

Lines, R. (2005). The structure and function of attitudes toward organizational change. Human Resource Development Review, 4, 8-32.

Luthans, F., Norman, S., Avolio, B., \& Avey, J. (2008). The mediating role of psychological capital in the supportive organizational climateemployee performance relationship. Journal of Organizational Behavior, 29, 219-238.

Maruyama, G. M. (1998). Basics of structural equation modelling. London: Sage Publications

Matheieu, J. E., \& Zajac, D. M. (1990). A review and meta-analysis of the antecendents, correlates, and consequences of organizational commitment. Psychological Bulletin, 108, 171-194.

Meyer, J. P., \& Allen, N.J. (1984). Testing the side bet theory of organizational commitmen: Some methodological considerations. Journal of Applied Psychology, 69, 372-378

Meyer, J. P., \& Allen, N. J. (1991). A three component conceptualization of or-ganizational commitment. Human Resource Management Review, 1, 61-89.

Meyer, J. P., Srinivas, E. S., Lal, J. B., \& Topolnytsky, L. (2007). Employee commitment and support for an organizational change: Test of the threecomponent model in two cultures. Journal of Occupational and Organizational Psychology, 80, 185-211.

Netemeyer, R. G., Bearden, W. O., \& Sharma, S. (2003). Scaling procedures: Issues and applications. London: Sage Publications.

Oreg, S. (2003). Resistance to change: Developing an individual difference measure. Journal of Applied Psychology, 88, 587-604.

Oreg, S. (2006). Personality, context, and resistance to organizational change. European Journal of Work and Organizational Psychology, 15, 73-101.

Oxtoby, B., McGuiness., \& Morgan, R. (2002). Developing organizational change capability. European Management Journal, 20, 310-320.

Palmer, I., Dunford, R., \& Akin, G. (2006). Managing organizational change: A multiple perspective approach. Singapore: McGraw-Hill Education.

Peccei, R., Giangreco, A., \& Sebastiano, A. (2011). The role of organizational commitment in the analysis of resistance to change: Co-predictor and moderator effects. Personnel Review, 40, 185-204.

Pfeffer, J. (1981). Management as symbolic action: The creation and maintenance of organizational paradigms. Research in Organizational Behavior, 3, 1-31

Piderit, S. K. (2000). Rethinking resistance and recognizing ambivalence: A multidimensional view of attitudes toward an organizational change. The Academy of Management Review, 4, 783-794.

Pulakos, E. D., Arad, S., Donovan, M. A., \& Plamondon, K. E. (2000). Adaptability in the workplace: Development of a taxonomy of adaptive performance. Journal of Applied Psychology, 85, 612-624.

Reichers, A. E., Wanous, J. P., \& Austin, J. T. (1997). Understanding and managing cynicism about organizational change. Academy of Management Executive, 11, 48-59.

Rousseau, D. M., \& Tijoriwala, S. A.(1999). What's a good reason to change? Motivated reasoning and social accounts in promoting organizational change. Journal of Applied Psychology, 84, 514-528.

Sagie, A., \& Koslowski, M. (1996). Decision type, organizational control and acceptance of change; An integrative approach to participative decision making. Applied Psychology: An International Review, 45, 85-92.

Schein, E. H. (1980). Organizational psychology, Oxford, England: Prentice Hall.

Schneider, B., Brief, A. P., \& Guzzo, R. A. (1996). Creating a climate and culture for sustainable organizational change. Organizational Dynamics, 24, 7-19.

Schweiger, D. M., \& DeNisi, A. S. (1991). Communication with employees following a merger: A longitudinal field experiment. Academy of Management Journal, 34, 35-110.

Snape, E., \& Redman, T. (2003). An evaluation of a three component model of occupational commitment: Dimensionality and consequences among United Kingdom human resource management specialist. Journal of Applied Psychology, 88, 152-159.

Swailes, S. (2004). Commitment to change: Profiles of commitment and in-role performance. Personnel Review, 33-187-204.

Tierney, W. G. (1998). The responsive university. Baltimore, Maryland: The John Hopkins University Press

Vakola, M., Tsaousis, I., \& Nikolau, I. (2003). The role of emotional intelligence and personality variables on attitude toward organizational change. Journal of Managerial Psychology, 19, 88-110.

Van Dam, K. (2005). Employee attitudes toward job changes: An application and extension of rusbult 
and Farrel's investment model. Journal of Occupational and Organizational Psychology, 78, 253-272.

Van Dam, K., Oreg, S., \& Schyns. (2008). Daily work context and resistance to organizational change: The role of leader-member exchange, development climate, and change process characteristics. Applied Psychology: An International Review, 57, 313-334.

Walker, J. H., Armenakis, A. A., \& Bernerth, J. B. (2007). Factors influencing organizational change efforts: An integrative investigation of change content, context, process and individual differences. Journal of Organizational Change Management, 20, 761-773.

Wanberg, C. R., \& Banas, J. T. (2000). Predictors and outcomes of openness to changes in a re- organizing workplace. Journal of Applied Psychology, 85, 132-142.

Wanous, J. P., Reichers, A. E., \& Austin, T. J. (2004). Cynicism about organizational change: An attribution process perspective. Psychological Reports, 94, 1421-1434.

WeiBo, Z., Kaur, S., \& Jun, W. (2010). New development of organizational commitment: A critical review (1960-2009). African Journal of Business Management, 4, 12-20.

Wijaya, T. (2009). Model empiris perilaku berwirausaha usaha kecil menengah di DIY dan jawa tengah. Jurnal Ekonomi dan Bisnis, 3, 119-131

Yousef. A. D.(2000). Organizational commitment as a mediator of the relationship between Islamic work ethic and attitudes toward organizational change. Human Relations, 53, 513-537. 